AGRIEKONOMIKA

http://journal.trunojoyo.ac.id/agriekonomika

Volume 10, Nomor 1, 2021

https://doi.org/10.21107/agriekonomika.v10i1.9983
Agriekonomika has been accredited as a scientific journal by the Ministry of

Research-Technology and Higher

Education Republic of Indonesia: No.

23/E/KPT/2019

SINTA 2

\title{
Reconstruction of the Social Capital-Based Agricultural Extension System in the Tengger Tribe Society in Tosari, Pasuruan, East Java, Indonesia
}

\author{
${ }^{凶 1}$ Ugik Romadi, ${ }^{2}$ Kliwon Hidayat, ${ }^{2}$ Keppi Sukesi, ${ }^{2}$ Yayuk Yuliati \\ ${ }^{1}$ Politeknik Pembangunan Pertanian Malang, Indonesia \\ 2Universitas Brawijaya, Indonesia
}

Received: Februari 2021; Accepted: April 2021; Published: April 2021

\begin{abstract}
This study aims to examine the "how" and "what kind of" implementation process of extension by the needs of the Tengger Tribe in optimizing their social capital as an effort to accelerate the process of information and technology transfer to achieve the goals of extension that have been outlined in the philosophy of extension, namely behavior change farmers as an effort to improve welfare. This research useed a qualitative approach with a phenomenological method. Based on the research found that a system and implementation of extension were needed by local conditions, and accommodates tribe characteristics. The reconstruction of the extension system must be carried out thoroughly in terms of the institutional aspects of extension, extension workforce, and implementation of extension so that it could achieve the expected goals of changing farmer's behavior to improve the welfare of farmers in the Tosari Sub-District of Pasuruan Regency.
\end{abstract}

Keywords: Reconstruction, Agricultural Extension System, Social Capital, Tengger Tribe.

\section{INTRODUCTION}

The extension is a learning process for the main actors and business actors so that they are willing and able to help and organize themselves in accessing market information, technology, capital, and other resources, as an effort to increase productivity, business efficiency, income, and welfare, and increase awareness in preservation of environmental functions (Law No. 16/2006). Based on this definition, agricultural extension "should" play an important role as an activity that is a catalyst, companion, intermediary, and inventor of solutions for farmers and agriculture as one of the cornerstones of agricultural development in Indonesia.

One of the factors that play a role in the success of agricultural extension is determined by the professionalism of extension workers, who have the main Corresponding author:

Email : ugik_yas@yahoo.com task as a guide, supporter, motivator, communicator, and others. Agricultural extension workers and prospective agricultural instructors must also have applicable and current capabilities as well as the ability to transfer or knowledge, with expectation can increase farmers' income and welfare and advancing Indonesian agriculture. Thus, the implementation of agricultural extension should no longer be top-down oriented but must be implemented bottom-up, and carried out systematically and continuously.

Based on an empirical review in Indonesia, that extension activities are necessary for terms of connecting information or extending the government as a trigger as well as a trigger, or more often said to be the "spearhead" of agricultural development. It's just that, since the reformation era in Indonesia in p-ISSN 2301-9948 | e-ISSN 2407-6260 
early 1998, and with the emergence of various new regulations that did not favor the importance of the future of agriculture, the role of extension by the government declined and added in early 2014 there was a policy of changing institutional extension that must be a merger with the technical service.

Based on empirical facts the results of previous studies are juxtaposed with an examination of the contents mandated in Law No. 16/2006 concerning SP3K and the reality that occurred at the Research site, there are gaps in the implementation of extension services in the field. The continuity and success of agricultural extension cannot be separated from the implementation of agricultural extension systems that exist today. The content, models, and methods of education carried out should pay attention to and involve various components intensively so that extension activities can be carried out effectively following their goals and objectives. In addition to these three things, ecological, individual, and tribe characteristics, including social capital owned by the extension target, are very important components that are the focus of attention to be optimized in the implementation of the extension.

Therefore, it is very natural that the implementation of agricultural extension to the Tengger Tribe must also be based and utilize on the social capital they have because the Tengger Tribe has very strong social capital characteristics. This is following Agricultural Government Regulation (Permentan) No. 03 of 2018 concerning Implementation of Agricultural Extension which emphasizes that the implementation of agricultural extension must also accommodate specific things to the needs of certain communities. So that be able to connect with the phenomena that occur in the environment of farmers with the development of science, both temporary and permanent, to the current agricultural extension system needs to be reconstructed.
Reconstruction of the agricultural extension system should be carried out thoroughly and intact both in terms of institutional, workforce, and implementation of the extension. While Sule et al. (2014), only studied the reconstruction of the agricultural extension system from the implementation side in Malang and Kaliky (2015), studied the reconstruction of the agricultural extension system from the institutional side in Maluku Province. From the results of studies that have been done both by Kaliky who only answer the problem in terms of institutional education, while what has been done by SuryamanSule et al only oriented to the needs of farmers who only answer in terms of organizing extension. So in this study examines the agricultural extension system from three aspects as a whole, namely from the institutional aspects of extension, aspects of extension, and aspects of organizing extension.

\section{METHODOLOGY}

This research was conducted in Tosari Sub-district, Pasuruan Regency, East Java Province. This research used a qualitative approach with a phenomenological method. The selection of this qualitative approach was felt to be very appropriate since this research focused on a process of change in a system, that the reconstruction of extension, which had been considered less relevant to the current conditions and developments.

Phenomenology is seen as a study that seeks to find the "essence" or meaning of a phenomenon that occurs and is experienced by social groups or some individuals (Creswell, 2015), which in the context of this study was the Tengger tribal tribe group located in the Tosari Subdistrict of Pasuruan Regency. In the context of this study, the researchers explored the meaning of the implementation of agricultural extension and the meaning of social capital by the Agricultural Extension Workers and the Tengger Tribe Tribe in 
the Tosari District of Pasuruan Regency. Through the phenomenological method, the purpose of exploring the meaning as a basis for making a reconstruction of the implementation of the extension system that was following the characteristics of the Tengger tribe was based on social capital owned. Pujilaksono (2016), argued that the study of phenomenology or studying the phenomena that occur is intended to explore and find out the deepest awareness of the research subjects related to experience and its meaning.

\section{Design Research}

The process of design (design) qualitative studies usually appear during research, but this design process follows the pattern of scientific research in general. In this study, the design process begins with general assumptions about the extension system in Tosari District, and the lens of interpretation I theoretical and research topics (Creswell, 2015). So based on this opinion, this research is directed to create and analyze social capital-based agricultural extension construction owned by the Tengger Tribe, so that it can find a reconstruction that is appropriate and relevant to the current situation and conditions, both from the conditions of the times and from aspects of values. values embraced by the Tengger tribe. Reconstruction carried out by researchers was seen from three fields, namely the field of institutional extension, the field of extension services, and the field of organizing extension. One of the main paradigms in communication science is the critical paradigm. To clarify the position of this research using the case study method, researchers must know and understand the paradigm that underpins this research, the critical paradigm.

\section{Research Focus}

The focus of research is the outline of research, so observation and analysis of research results will be more directed. In this study, researchers focused on analyzing and compiling the reconstruction of agricultural extension systems based on social capital owned by the Tengger Tribe tribe. The Tengger tribe in question is the Tengger tribe in the Sub-district of Tosari, Pasuruan Regency, and the extension system in question is an extension system implemented in the Tosari sub-district based on social capital owned by the Tengger tribe.

\section{Determination of Informants}

As with the type of qualitative research, this study uses informants as sources of data and information, which are expected to provide the information needed to find out the reconstruction of the extension system. The informants were agricultural instructors, agricultural paramedics, tribe leaders, and farmers of the Tengger Tribe. Determination of informants in this study was carried out in stages, are:

a. Selection of initial informants related to the focus of the study consisted of 4 informants, namely Agricultural Extension Workers, Farmers' Mantri, Farmers, and Tribe Leaders.

b. Selection of follow-up informants to other informants to expand information and provide variations in the information that might be available to Agricultural Extension Workers, Farmers, and Tribe Leaders.

c. Data saturation is reached when there is enough information to replicate the study when the ability to obtain additional new information has been attained, and when further coding is no longer feasible.

The determination of informants is carried out deliberately by considering the characteristics of the informants that support in extracting research data. One aspect of this research is social capital, so the selection of informants needs to consider age and role to bridge the information needs related to social capital owned by the Tengger Tribe. To obtain an overview of the existing outreach construction and social capital it possesses, informants who have an understanding of social structure are needed, the system 
of organizing extension includes power relations. Therefore, informants from the government apparatus especially those in charge of the extension, paramedics, village officials, and tribe leaders are needed. Likewise, regarding extension activities, informants of extension agents are expected to provide information related to extension activities.

\section{Method of Collecting Data}

In qualitative research, data collection was obtained using 3 techniques, which are interviews, participatory observation, and documentation (Gunawan, 2013). Meanwhile, according to Djamal (2017), data collection techniques consist of 5 techniques, which are observation, interviews, documentation, focus group discussions, and triangulation. In this study researchers conducted several stages in data collection namely in-depth interviews, observations, documentation.

\section{In-depth Interview (in-depth interview)}

Broadly speaking, interviews can be divided into structured interviews and unstructured interviews. Structured interviews look for answers to work hypotheses. The questions are arranged neatly and strictly in the interview protocol. Unstructured interviews have the characteristics of less interruption and arbiter. This kind of interview is used to find information that is not standard or single information (Moleong, 2005).

The interview used in this study was unstructured. This interview was conducted with open-ended questions that led to the depth of information and were done in a way that was not formally, to explore the views of the subjects studied about many things that are very useful to be the basis for further and deeper exploration of information. During the interview process, the researcher recorded and recorded the results of the interview.

There are three types of questions in the interview used in this study, which are descriptive, structural, and contrast questions. Descriptive is used to obtain an overview of an object, event, setting, or other information from the informant in this study, which is a description of the implementation of agricultural extension, social capital owned by the Tengger tribe, and agricultural activities carried out. This type of question is the most widely used in daily life. Structural is useful for verifying the scope of the content contained in a particular symbolic category, for example regarding the meaning of agriculture, extension, and social capital both from the farmer side and from the extension side. While the contrast question is intended to trace the characteristics of a concept by providing a comparison or contrasting matter.

Observation (Participation Observation) In this study, researchers used participant observation as observers. The observation was carried out by observing the habits or activities carried out by extension agents and farmers in implementing the implementation of agricultural extension to 15 informants. Observations were made to obtain data on social phenomena made by agricultural instructors in implementing agricultural extension systems in the Tengger Tribe. Observations are also intended to check the results of the interview. Observations can also be made by participating directly in the activities of the implementation of extension, it is by involving themselves in the process of conducting extension is one of the strategies to prevent suspicion on the object of observation.

\section{Documentation}

In this study, researchers need accurate data that is relevant to current conditions, both primary and secondary data. Primary data is data taken from primary data sources or the first source in the field in the form of interviews with 15 informants. While secondary data is data obtained from a second source or secondary source, which has been arranged in the form of documents such as data on the 
demographic condition of an area which in this activity is Pasuruan Regency Data in Numbers (Bungin, 2001).

\section{Validation of The Data}

The validity of the data is carried out in three stages, it is the credibility of the data is carried out by triangulation and member checking, Dependability, and Confirmability. Triangulation means that various data regarding changes in the socio-economic life patterns of the Tengger Tribe that occur successfully collected compared between one data source with another. Member check, it is intended that researchers try to involve some informants to confirm the data and interpretation including with colleagues to maintain the credibility of the data. So in this study, the researchers used several informants both from farmers and from extension agents.

This criterion is used to maintain prudence so that it can be avoided the possibility of errors in collecting and interpreting data, or in other words, the dependability test is carried out by auditing the entire research process in which the dependability process is conducted by the supervisor through the guidance process.

Almost the same as the activity of dependability which emphasizes caution in maintaining and assessing the results of research by consulting competent parties in conducting qualitative research study results. Confirmation testing in this study was conducted by testing the results of research associated with the process that has been carried out during the research in the Tosari Sub-district, Pasuruan Regency. This process is carried out to ensure that the results that have been obtained are truly through the research process because the research does not let the process not exist but the results are there.

\section{Data Analysis}

This study used qualitative analysis methods. The qualitative data analysis model conducted by researchers was the method developed by Miles, Huberman, and Saldana (2014), namely the interactive model. In general, this process included the flow of activities that occur simultaneously, namely Data Condensation, Data Display, Drawing Conclusions. In this study, the researchers conducted an interview process which was then recorded as a field note from the researcher, then presented and sorted based on groups of answers that tended to be the same so that it could be used as data to conclude.

Data condensation refered to the process of selecting, simplifying, extracting, and/or transforming data that approaches the entire portion of field notes in writing, interview transcripts, documents, and other empirical data relevant to research needs.

Next was the process of presenting data, which was an organization, the integration of information that enabled inference and action. Presentation of data helped in understanding what was happening and to do something, including in-depth analysis or taking action based on understanding, and if it was still lacking from the existing data, it could be extracted again in the process of collecting data.

The next process was drawing conclusions and verification. From the beginning of data collection, the researcher began to search for the meaning of objects, noting the regularity of explanations, possible configurations, causal flows, and propositions, "final" conclusions may not appear until the data collection ended, depending on the size of the collections. field notes, coding, retention, and retrieval methods used, researcher skills, and donor requirements.

\section{RESULTS AND DISCUSSION}

Some basic facts and problems related to the application of agricultural extension systems in the District of Tosari, Pasuruan Regency are how the process of delivering information and agricultural technology innovations can be accepted and then applied to the people of the Tengger tribe equally and thoroughly all groups, both young and old. It only covers one paradigm from the four existing education paradigms, which is the technology transfer 
paradigm. The geographical conditions of the mountainous region with an average steep slope and limited availability of water sources and the majority of temperate $B$ (wet) have an impact on the lack of maximum use and application of modern agricultural equipment and machinery. In addition, the limited number of extension workers who have not been supported by adequate facilities, the background of the memory of the formation of farmer groups, the impact of the mismatch between government assistance and tribe needs, the typology of assistance, and the mismatch of target beneficiaries, also have an impact on the activeness of farmer groups in the Tosari District. These various conditions are interrelated with one another so that it has the potential to become an obstacle in the realization of good agricultural extension services for the Tengger people who live in the region.

The extension system in Tosari Subdistrict, Pasuruan Regency in terms of institutional extension, implementation is still not able to answer the needs of the Tengger tribe so that breakthroughs and adjustments need to be done so that it can be implemented properly. Based on the research results it shows that a system and implementation of extension is needed that is arranged by local conditions and accommodates tribe characteristics.

Some notes that need attention in the effort to reconstruct extension in Tosari Sub-district are closely related to the lives of the people of Tengger by noting that:

a. Extension officers must be part of the tribe, so that together (not camouflage) can join hands as partners to help each other in improving people's lives and welfare. The approach taken by the instructor to be able to "enter" to be part of the tribe is very dependent on the ability of each instructor. Therefore, extension workers must be equipped with the ability to adapt to society through a variety of methods and approaches, the implementation of which is highly dependent on the abilities of each individual and the tribe that will become their partners. "Adaptation competence" is something that should be considered with other soft skills that must accompany it. Officers who are placed in specific environments such as the Tengger tribe, "should" not only have good hard skills but also have good soft skills as well.

b. To carry out their work properly, extension workers should not be bound by working hours or bound by administrative activities. The time spent for the tribe "cannot be limited by working hours" and should be an "added value" for the instructor in carrying out his activities as a public servant. These conditions must be distinguishable from the "values" that must be achieved by extension agents as servants of the state. Performance measurement of extension workers should be able to adapt their field activities which do not always have to be measured by "performance outputs" or "completed work units", but rather to the sequence of work they carry out to benefit the tribe. If necessary, "assessment of instructor performance is carried out by the tribe" of the fostered area and recorded as an inseparable part of the performance of instructors, so that an objective picture of the performance of duties as state servants and tribe servants is obtained. It also cannot be used as an excuse to avoid activities and administrative evidence that must be fulfilled by a civil servant, so there is a need for collaboration between administrative and field conditions, so that in certain specialties, for example in proposing credit numbers, it is necessary to providerecommendations/ performance from the target area as evidence the performance of an agricultural instructor.

c. Tribe needs for the existence of extension workers and extension must be formulated appropriately. Therefore, we need "instruments" that can capture the "needs of the tribe" 
for the extension. Although up to now one of the instruments in the form of Regional Potential Identification (IPW) has been determined, not all instructors can adopt the "essence" of the instrument. Although the preparation of agricultural extension programs should always begin with the identification of regional potentials, discussions, and "brainstorming" with tribe leaders, extension programs still become "documents" that cannot yet be fully used as work references, because they cannot be operationalized. This happens for several reasons including; a) the source of information chosen by the instructor as a source of data mining is less able to define all the potential they have, b) the emergence of "vested" (personal interests) from the sources of information regarding the activities to be carried out, $c$ ) the competence of the data mining actors still needs to be improved, or even (and is often found to date) well-planned planning that does not get support from stakeholders due to various external factors that cannot be controlled (for example, there is no budget support available). The complexity and interrelationships among several elements as stated above make the existence of extension workers and various planning activities on information only on paper without being able to be implemented. Because these experiences continue to occur and recur, the tribe becomes "skeptical" of agricultural extension and extension services.

d. The concept of extension cannot be "nationalized" because it is sitespecific and based on the tribe's basic real needs. To answer this, actually facilitated by the mechanism of the preparation of agricultural extension programs, villages, districts, cities, provinces to the national. However, the documents that have been prepared can rarely be carried out in the field. The concept of "decentralization" of extension, which follows the laws and regulations, should also be balanced with the adaptation of local governments to their budgetary structures. This will not necessarily solve the problem, because the indicators of government success both central and regional are almost always associated with quantitative measures, and of course, different approaches to the development of farmer resources, which lead to increased productivity, increased income, and lead to an increase in farmers' welfare. Indicators of human resource development through extension are often "considered non-existent" because they cannot be measured quantitatively. Increased productivity of the land obtained from the harvest, as if considered "not the result of extension work", so it still appears the notion that "extension is not an important thing" to do. This stigma is still very dominant in the minds of the wider tribe so that it is a challenge for the government to set it straight.

e. The reporting system of extension activities should adjust to field activities. As a state servant, the demand for performance accountability is a necessity that must be fulfilled by the instructor in carrying out his activities, including the need for the preparation of credit figures for promotion. Thus, the "measure" of the instructor's performance "should not only" be an activity that can be easily measured for the achievement of its output, but should be more respectful of activities that are "qualitative". Quantitative evidence that is often difficult (for example the number of farmers presents in extension activities), the suitability of field activities and planned agricultural extension activities (RKPP), extension media used and various other indicators, should be reviewed. Instead, the reporting activities of extension workers can be integrated into a system that accommodates the progress of information technology. 
Thus, the instructor's performance output can be measured by applicable regulations, and on the other hand, the tribe's need to always be close and interact with the instructor in building human resources can be realized.

The main social capital possessed by the Tengger tribe: in the form of trust in others, surrender to what is obtained, and work hard to meet basic living needs, are values that are held in high esteem and are used as the basis for rules and norms in social life. Whether or not there are government officials or officers from plant medicinal plants, farmers will continue to work to meet their basic needs namely "the need to survive" through businesses on agricultural land they own. They do not seem to care about the frenetic outside world, they are firm, consistent, open, honest, and appreciate what they and others have. The sincerity and innocence of the Tengger tribe in interacting with others illustrates that they are people who can be trusted, and conversely they look very respectful of others when they have interacted with them. Materializaton from social legal capital posed at bay trust; values; social norm; participation in chain and also resiprocity require to be involved in management implementation as science and artistic, in order to organization stand at bay in emulation in business world (Supono, 2011). A tangible manifestation of social capital that is so strongly attached and well maintained to the present.

Reconstruction of the Agricultural Extension System in terms of Institutional, Employment, and Implementation of the Agricultural Extension System can be seen in the following figure 1.

The reconstruction of the extension system must be carried out thoroughly in terms of the institutional aspects of extension, extension workforce, and implementation of extension so that the implementation of extension can achieve the expected goals of changing farmer's behavior to improve the welfare of farmers in the Tosari sub-district of Pasuruan Regency.

The role of social capital as a survival strategy: 1) the establishment of social relationships/interactions among members of the community that can foster brotherhood, kinship and kinship; 2) the strength of social solidarity in the community; 3 ) trust in the community fosters mutual attitudes to help; 4) preserving traditions in the life of Mary's society; and 5) social values and norms which act as tools of social control. The

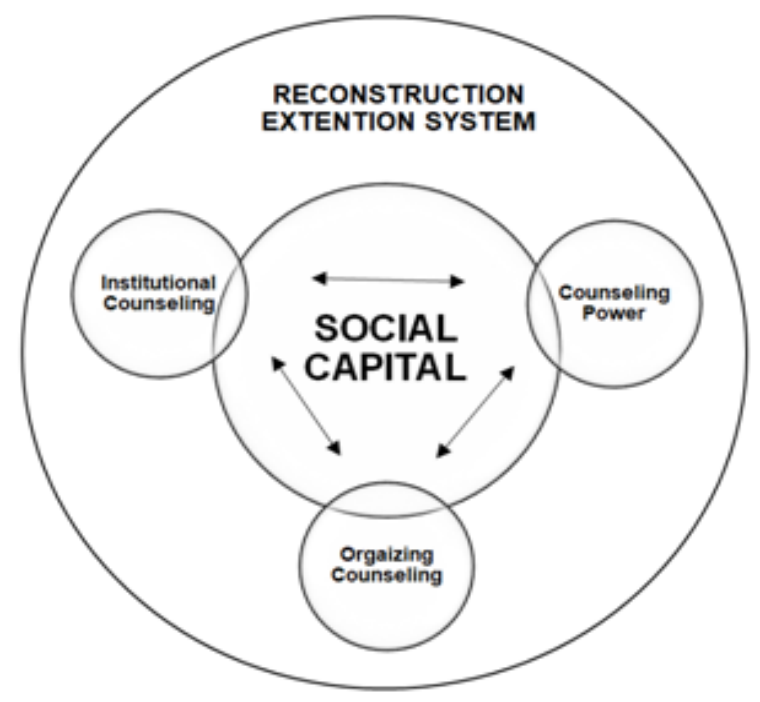

Source: Processed Data

Figure 1

Reconstruction Of Extension Agricultural System 
role of the community in developing social capital: 1) the community participates in the development of social capital in Maria Village seen in cooperation or involvement carried out among community members such as youth organizations, youth mosques, village youth associations and so on; 2) the attitude of the community in developing social capital is very open, it is seen that the village community of Maria is open to change (Solikatun, 2018).

From the institutional aspect which is still inconsistent up to now because it is highly dependent on local government policy, it is necessary to involve the customary institutions owned by the local area. The involvement of traditional institutions is expected to help smooth the implementation of extension activities. From the aspect of workforce, which is based on the needs of extension workers in one village, there will be a shortage of instructors, so there needs to be involvement of private and private extension workers and the determination of tribe and agricultural leaders as selfhelp instructors in one coordination by civil servants. The civil servant instructor acts as a coordinator at the sub-district level who synergizes with private extension workers and self-help extension workers so that the assumption of shortage of extension workers can be minimized. While the implementation of extension which until now both from existing regulations and implementation in the field still tends to be top-down, there needs to be a very fundamental change where previously it was only done through the preparation of agricultural extension programs, the determination and manufacture of extension materials, the determination of extension methods and continued with the implementation agricultural extension must be changed beginning with careful planning (starting from the needs of the extension target, setting and making materials, setting methods and making agricultural extension media), followed by the stage of implementing agricultural extension (delivery of material, media use and determination and application of agricultural extension methods) ), and ended with the evaluation phase both in terms of evaluating the planning phase, evaluating the implementation phase and evaluating the impact of implementing agricultural extension activities.

\section{CONCLUSIONS}

Various factors that limit the existence of extension institutions at the government level, the involvement of non-formal institutions in the tribe becomes a necessity in the development of the extension. The minimum number of extension workers can be overcome by recruiting advanced farmers to become partners so that they can jointly develop the tribe. The recruitment should be accompanied by an award to advanced farmers as a form of government concern and a guarantee of sustainability. The concept of extension cannot be "nationalized" because it is sitespecific and based on the tribe's basic real needs. Extension agents should not be bound by working hours or be bound by administrative activities. The time spent for the tribe "cannot be limited by normal working hours" and should be an "added value" for the instructor in carrying out his activities as a public servant.

\section{REFERENCES}

Bungin, B. (2001). Metode Penelitian Sosial "Format-format Kuantitatif dan Kualitatif". Airlangga Universiti Press. Surabaya.

Creswell, J. W. (2015). Penelitian Kualitatifdan Desain Riset. Pustaka Pelajar. Yogyakarta.

Denzin, N.K dan Lincoln Y.S. (2009). Handbook of Qualitative Research. Pustaka Pelajar. Yogyakarta.

Djamal, M. (2017). Paradigma Penelitian Kualitatif "edisirevisi". Pustaka Pelajar. Yogyakarta.

Gunawan, I. 2013. Metode Penelitian Kualitatif. Bumi Aksara. Jakarta. 
Kaliky, R., Hariyadi, S. S., Subejo. (2015). Rekonstruksi Sistem Penyuluhan Pertanian di Maluku. Agrica Ekstensia, 9(1), 16-26.

Miles, M. B., Huberman, A. M., dan Saldana, J. (2014). Qualitative Data Analysis, A Methods Sourcebook, Edition 3. USA: Sage Publication.

Moleong, J. 2005. Metode Penelitian Kualitatif. PT. Remaja Rosdakarya Offset. Bandung.

Permentan Nomor 03/PERMENTAN/ SM.200/1/2018 tentang Pedoman Penyelenggaraan Penyuluhan Pertanian. Kementerian Pertanian. Jakarta.

Solikatun, J. N. (2018). Modal Sosial Sebagai Srategi Bertahan Hidup Masyarakat Desa Maria, Kecamatan Wawo, Kabupaten Bima, Provinsi Nusa Tenggara Barat. Jurnal Analisa Sosiologi, 7(2), 262-273.
Sule S, S., dan Purnomo M. (2014). Rekonstruksi Sistem Penyuluhan Pertanian Berbasis Kebutuhan Petani Pada Program FEATI. Jurnal Agriekstensia, 13(2), 167-183.

Supono, B. (2011). Peranan Modal Sosial dalam Implementasi Manajemen dan Bisnis. Jurnal Ekonomi dan Kewirausahaan, 11(1), 10-16.

Undang-Undang No. 16 Tahun 2006. Sistem Penyuluhan Pertanian, Perikanan dan Kehutanan (SP3K). Jakarta.

Yin, R.K. 2002. Studi Kasus "Desain \& Metode". Rajawali Pers. Depok.

Yusuf, A.M. 2014. Metode Penelitian Kuantitatif, Kualitatif dan Penelitian Gabungan. Prenada Media Group. Jakarta. 
98 Ugik Romadi et al., Reconstruction of the Social Capital-Based Agricultural Extension System

Appendix 1. Reconstruction of Institutional Agricultural Extension

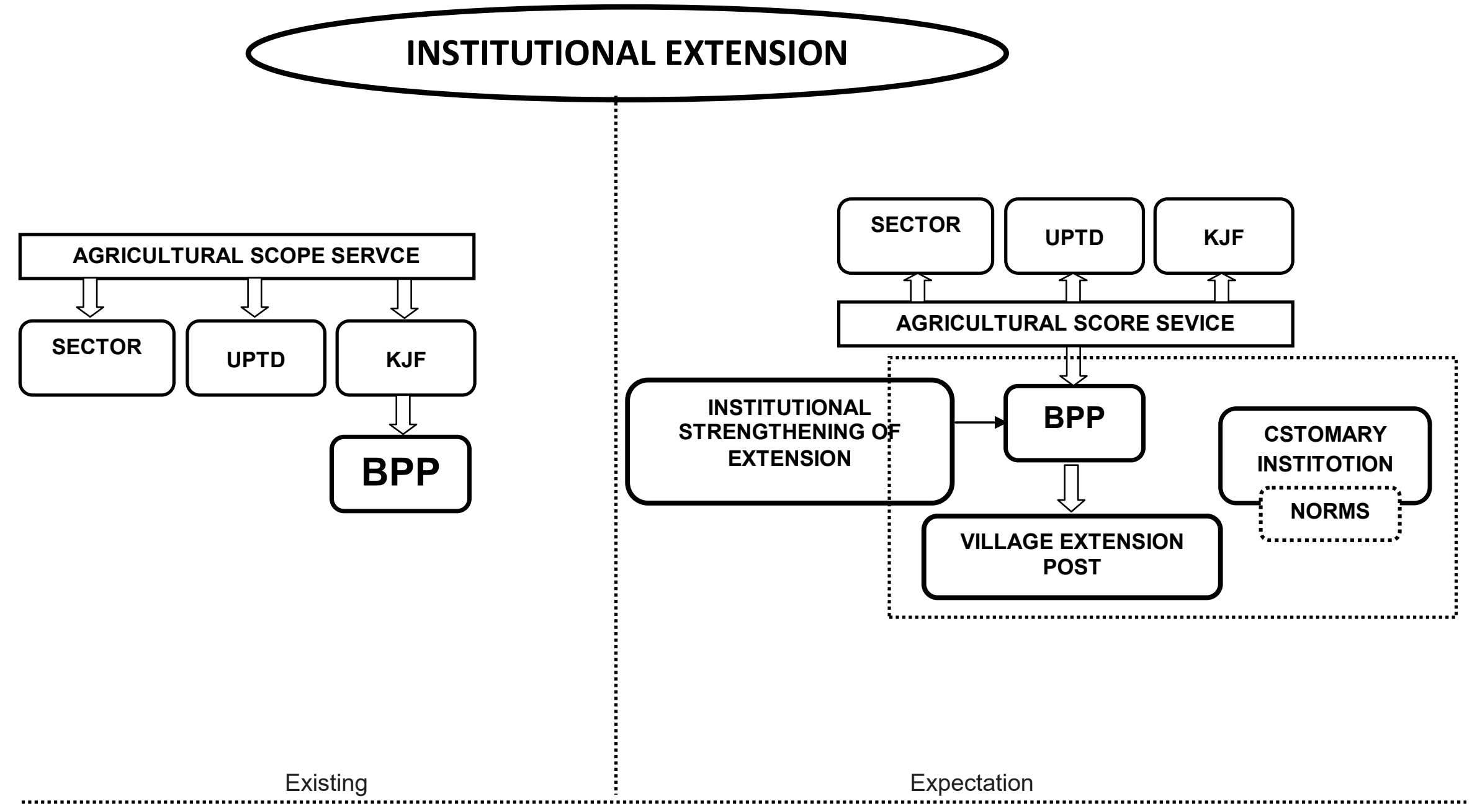


Appendix 2. Reconstruction of Agricultural Extension Workers

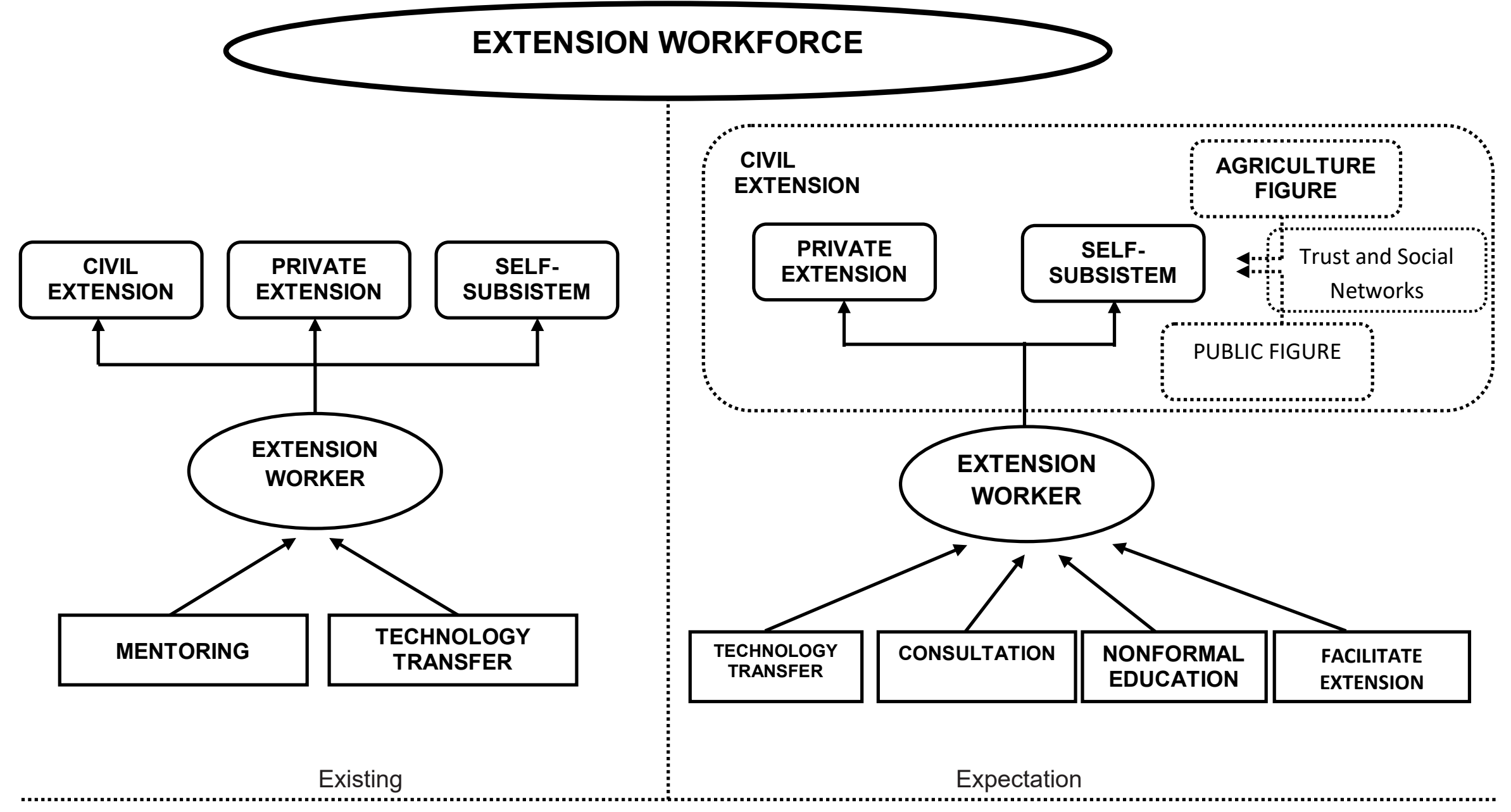


100 | Ugik Romadi et al., Reconstruction of the Social Capital-Based Agricultural Extension System

Appendix 3. Reconstruction of Agricultural Extension Service

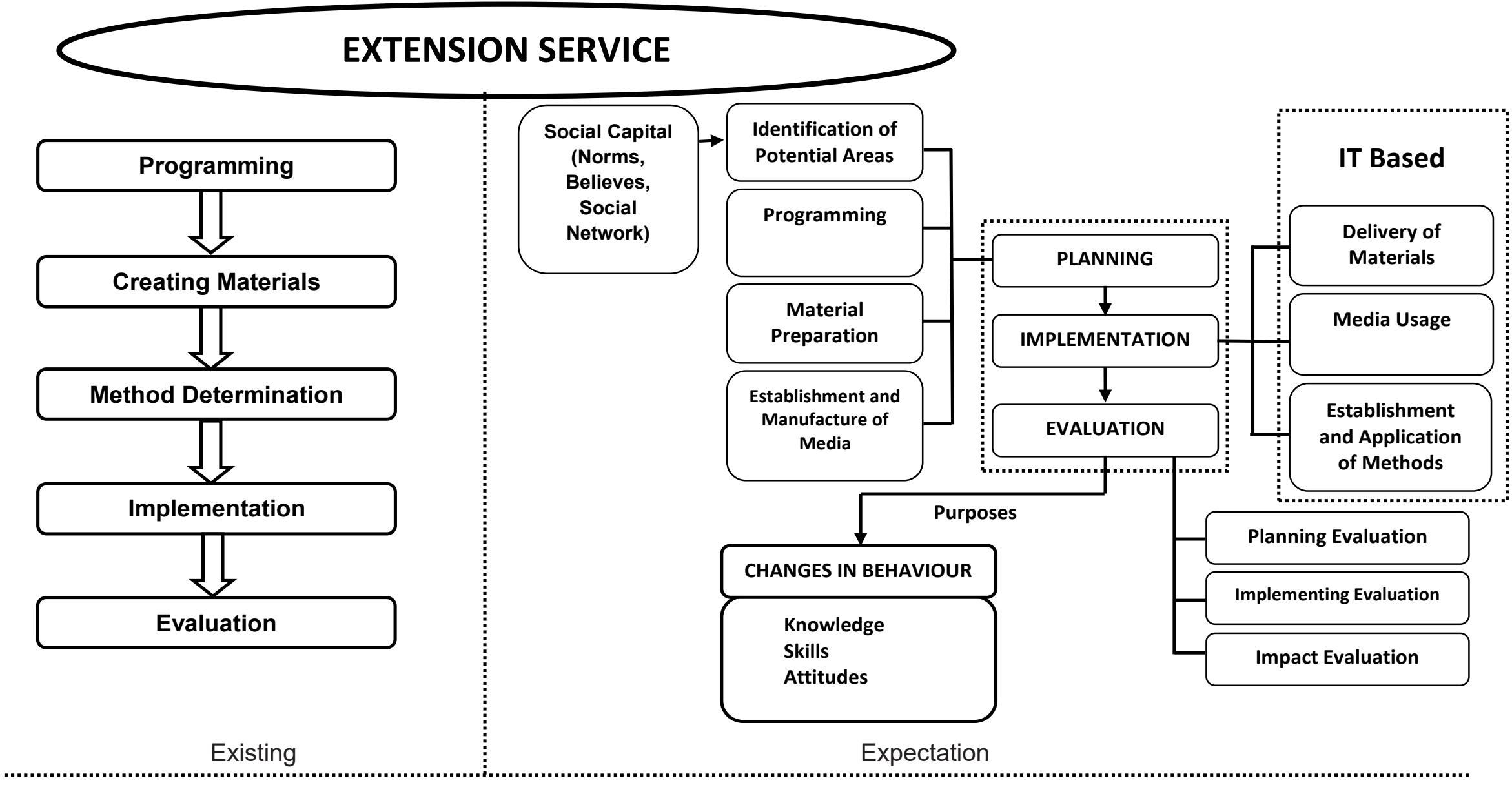

